\title{
STATE COMPACTS AS A METHOD OF SETTLING PROBLEMS COMMON TO SEVERAL STATES *
}

\section{Willtam J. Donovan $\uparrow$}

In a system of government involving the existence of forty-eight sovereign states it is inevitable that disputes will arise between the states. These disputes involve not only questions of balance of power between state and federal organizations, but also controversies which are in their nature the subject of common concern to more than one state while not presenting issues affecting the entire nation. We find examples today in such problems as extradition, jurisdiction over harbors which contain in their limits the boundaries of more than one state, the wholesale interstate transmission of power and riparian rights in interstate rivers. The development of our territory and the growth and intensification of our industrial life present new regional and sectional problems.

As these problems arise, we look to the Constitution to ascertain if not the specific means at least the basic philosophy for dealing with them. We find that the framers anticipating that interstate disputes would arise, embodied in the fundamental law not the theoretical function of an Utopian state, nor particular remedies for specific problems, but certain practical and flexible means that they believed were suited to conditions in a new and constantly growing country.

Under the Constitution, there are three methods of determining disputes between states. One means is by direct legislation of Congress. This method is limited to that field where the states have granted that right under the Constitution. Examples are found in the authority of the Congress to legislate in regard to navigable state waters and in the field of interstate commerce. This method does not afford a comprehensive means of settling all disputes between the states.

The second method, that of litigation, is governed by the provisions of Article Three of the Constitution. Section 2 of Article Three provides, among other things, that "The judicial Power shall extend . . . to Controversies between two or more States."

*An address, with slight revisions, delivered in Philadelphia, March 24, I93I, before the Juristic Society, a group composed of younger members of the bar of Philadelphia whose aim is to stimulate interest in the academic aspects of the law.

TA. B., I905, LL. B., I907, Columbia University; Assistant Attorney General of the United States, 1924-25; Assistant to Attorney General, I925-29; representative of United States on Rio Grande River Compact Commission and Boulder Canyon project; counsel to commission for revision of New York State public service commission laws, I929; member of delegation representing United States in conference between Dominion of Canada and United States relative to customs regulations between the two countries, I923; member of American Bar Association, New York State Bar Association. 
The cases under this provision decided by the Supreme Court have been collected and annotated. They are about seventy-five in number and deal principally with boundary disputes, extradition, public health and riparian rights in interstate rivers. Such cases by their scope exact of the Supreme Court a terrific price in time and labor. Out of the necessity of narrowing the controversy to a legal issue, the result is too often unsatisfactory. Not all matters in dispute between the states can be settled by judicial determination. The Supreme Court has recognized its own limitations and has suggested in more than one case that the party states seek their remedy by conference and agreement. Many problems by their very nature demand continuous supervision and local control. Sporadic litigation does not in such cases afford a satisfactory remedy.

The third method, that of settlement of disputes between the states by means of compacts, also has its source in the Constitution. Article I, Section IO, subdivision 3, provides in part: "No State shall, without the Consent of Congress, . . . enter into any Agreement or Compact with another State, or with a foreign Power . . ." The records of the Constitutional Convention fail to show exactly what the framers intended by this provision. However, history discloses that with the growth of the colonies prior to the Revolution, disputes as to boundaries frequently arose. Two distinct methods of settling such conflicts were pursued. One method was in effect that of present-day litigation. This involved laying the dispute before the Crown, which resulted usually in the appointment of a royal Commission to hear the dispute. When the Commission rendered its decision, either party might appeal to the privy council. The other method was by negotiation and agreement. When the contending colonies reached an agreement, it was necessary to secure the approval of the Crown. That approval sanctioned and validated the agreement arrived at by negotiation. It may be that the existing provision of the Constitution was intended to perpetuate that mode of settlement.

A distinction may be drawn between the requirements of subdivision 3 of Section Io and the prohibition contained in subdivision I of the same section which provides inter alia that "No State shall enter into any Treaty, Alliance or Confederation ... ." In order to establish the sovereignty of the Union for purposes of international relations, it was essential that the states should not enter into any alliance or confederation and that treaties should be entered into only by the federal government. A treaty between the states would in itself be destructive of national sovereignty. A compact or agreement, however, would not necessarily be destructive of national sovereignty although it might involve issues affecting the entire nation. So it is that, while Congress cannot authorize the state to enter into any treaty, alliance or confederation, agreements between the states 
may be made and to protect the national interests it is provided that the consent of Congress must be obtained. Such consent may be given before or after the agreement is entered into.

The compact itself may be the result of direct legislative acts. In these cases the legislature of one state makes an offer which is accepted by an act of the legislature of another state. The agreement so arrived at constitutes a compact between the states provided, of course, that the consent of Congress is obtained. This method is practicable only where the problems involved are simple. Complex problems cannot be readily dealt with by action of the legislature and can best be solved through negotiations conducted by commissioners having the benefit of expert technical advice.

A study of the actual cases in which the compact method has been used indicates that it is a fruitful means of settling disputes between states. ${ }^{1}$ The compact has been used with marked success in settling disputes as to boundaries and jurisdiction over boundary waters for specific purposes. It provided a method for solving the differences between Kansas and Missouri in the erection, operation and maintenance of water works. In this manner Virginia and Maryland dealt with mutual problems in the regulation of navigation, fishing and the exercise of jurisdiction over the waters of the Potomac River. It was utilized by New York and New Jersey to effect the construction and operation of tunnels between those states. $\dot{B} y$ this means the same states were able to adjust their differences in regard to jurisdiction over New York Harbor and to provide a comprehensive plan for the continuous development of the port. The compact in that case provided for the creation of a commission to be known as the "Port of New York Authority" and full administrative powers were conferred upon this commission in order that it might be equipped to deal effectively with problems common to both states involved in the development of the harbor.

Just as nations have composed their differences concerning international rivers by treaty, so the interstate compact has had its greatest development in the dealing with the rivers of the Western states. It is said that of the twenty-six states east of the Mississippi, the rivers of ten are covered by compacts and of the twenty-two states west of the Mississippi, twenty are involved in river compact negotiations.

The compacts respecting these western rivers evolved from interstate river litigation over a period of twenty-five years. In the west while land is plentiful, water is scarce. All the large rivers flow through or have their tributaries in two or more states. The inevitable recurrence of dry years produced conditions out of which arose prolonged, expensive and extremely unsatisfactory litigation. The Western states learned that litigation when

${ }^{1}$ A compilation of interstate compacts has been made by a pioneer in the compact field, CARPENTER, INTERSTATE RIVER COMPACTS. 
finally determined did not settle questions which went far beyond the domain of a particular lawsuit. They saw also that by this failure to settle their difficulties they were opening the way for the assertion by the federal government of control over water rights. They found in their litigation federal representatives contending that the United States owns and may control and dispose of the waters of the western rivers regardless of the will of the states. These considerations brought home to them the immediate need of a more comprehensive method of solving their river problems.

The first river case in which an interstate compact was used by those states was in the South Platte controversy, ${ }^{2}$ involving Nebraska and Colorado. The suggestion of a compact was then made by Delph Carpenter, counsel for Colorado. This was the pioneer move in that field. Although negotiations began in I9I6 they were not concluded until 1923 and approved by Congress in I926. In the meantime other compacts had been instituted and completed.

The latest of these agreements, the Rio Grande compact, made between New Mexico, Texas and Colorado, was approved in June, I930, by Congress. $^{3}$ It determined the rights of the three states to the waters of the Rio Grande for five years and laid the foundation for the permanent settlement of a controversy of long standing.

The greater part of the large irrigation projects in the west are interstate in character. They are located upon interstate rivers and their uninterrupted development necessitates the determination in advance of rights, in order to avoid litigation. Capital will not invest in securities for power, for irrigation or other purposes based on uncertain titles to the use of waters of interstate rivers. All these problems can be determined in advance by agreement. In actual practice by the use of this method there have been settled vital matters to the Western states such as: preference - of uses in times of water scarcity, guarantees that more important uses will be served over less imperative demands, assurance of sufficient water to supply the future needs of states in which the streams originate and provision of adequate supply for essentials in states in the lower reaches of the rivers. By this means the whole river system is developed in a manner best calculated to obtain the maximum benefits from the common water supply. Boards are appointed to control and administer uses, enforce prohibitions and oversee the most effective disposition of the streams to the benefit of the territory as a whole.

In order to understand fully the water problem of the West it is essential to understand the system of water law generally governing the uses of water in that section. As distinct from our riparian system they have what

'72 CoNG. Rec. 8579, IO43I, III62 (I930). 
is called the rule of priority or of appropriation. Under either system, a water right is not ownership of the water itself as it exists in the natural source of supply, but rather of a right to make use of the water. But in other respects they differ radically. The basic principle of the riparian system is that of equality among the riparian proprietors not of an equal amount, but an amount which, under all the circumstances would constitute an equitable division of the waters. The priority system on the contrary is based not on equality but on discrimination-discrimination in favor of the prior user or, as he is called, appropriator. In this system it is the first user who obtains the highest right and he need not be a riparian owner.

The priority system and mining law are the two bodies of substantive law given to American jurisprudence by the West.

The priority system is said to have inaugurated with the "FortyNiners." It spread from mining uses to irrigation purposes and today seventeen states enforce the system either wholly or in part and allow the waters to be used for all beneficial purposes. The earliest reported case sustaining this doctrine was $E d d y$ v. Simpson, ${ }^{4}$ decided in I853. The first legislative recognition was by the State of California in I85I and by the United States by the Act of July 26, I866, when the public was permitted to mine in the public domain. The first judicial decision of the United States Supreme Court was in Atchison v. Peterson ${ }^{6}$ in 1874.

It is generally doubted that Congress has the power to provide for the settlement of an interstate stream controversy. The Supreme Court by virtue of its original jurisdiction of such a dispute may formulate a principle in deciding suits between the States. It has so far evolved two doctrines. They were stated in the cases of Kansas v. Colorado, ${ }^{7}$ and $W y o m$ ing v. Colorado. ${ }^{8}$ The first case was Kansas v. Colorado. Kansas was a riparian state and Colorado a priority state. The Court there held that an equitable division of water should be made between the two states, regardless of state lines, by taking into account the volume of flow, the periods of flow, the needs of the two states, the present use of water, and the future demands which might be made upon the stream. In Wyoming v. Colorado, the Supreme Court recognized the doctrine of priority that obtains in both states. Here they ascertained the average commercially dependable flow of the river, created a water fund and divided all the water in the fund between the states in order of the establishment of prior rights and without regard to state lines.

' 3 Col. 249 (1853).

${ }^{\circ}{ }_{4}$ STAT. 253 (I868), 30 U. S. C. A. \& 5r (1927), 43 U. S. C. A. \$66r (I928).

${ }^{\circ} 20$ Wall. 507 (U. S. I874).

${ }^{7} 206$ U. S. 46, 27 Sup. Ct. 655 (I907).

${ }^{8} 259$ U. S. 419, 42 Sup. Ct. 552 (I922). 
As a result of the decision in Wyoming v. Colorado laying down the principle of interstate priority rather than equitable division between states, it was feared that every federal irrigation or reclamation or power project upon an interstate stream would precipitate a conflict among all the states upon that stream. In such a situation there must be some method by which all issues can be determined, and a plan worked out by which future differences can be reconciled.

The present controversy over allocation of water and the development of the water power of the Colorado River furnishes an illustration. It cannot be solved by the action of a single state or by congressional legislation alone. It exemplifies the importance of statecraft in the settlement of such problems.

The Colorado River, I293 miles in length, is the third largest river on the continent. Not only is it an interstate stream but it is international as well. It has its source in Colorado and flows south and west through the states of Utah and Wyoming, forms part of the western boundary of Arizona and the eastern boundary of Nevada, California and Mexico. It flows through Mexico a distance of seventy-five miles and empties into the Gulf of California. The river is fed by tributaries from New Mexico and all these named states excepting California.

The drainage basin of the river has a total area of 244,000 square miles. All of the land in this drainage basin is arid in character, so that in order to grow crops irrigation is necessary. The welfare and prosperity of this great southwestern plateau is largely dependent upon the river. The future growth and progress of the region are greatly contingent upon the reclamation and irrigation of additional land in each state.

In I92I, in recognition of their common problem and in an effort to avoid litigation and controversy between the states, the states concerned and the federal government enacted legislation providing for the appointment of commissioners by the governors of those states and by the President of the United States to negotiate a compact for the equitable apportionment of the waters of the Colorado River.

In I922 a compact was finally entered into under the terms of which the river system was divided into two basins. The upper, comprising generally Utah, Wyoming, Colorado and New Mexico, and the lower, which included Arizona, California and Nevada. It was assumed that there were approximately $18,000,000$ acre feet of water in the river and 7,500,000 acre feet were apportioned to each of these basins with the provision that at a later period there would be further equitable apportionment. The theory of the compact was that although the upper basin states did not use all of the water allocated to their use, they would be free to proceed with 
their development both for power and for irrigation, and yet leave to the lower basin states water sufficient for their needs.

Water which could be applied to agricultural and domestic uses was not to be withheld. Navigation was made subservient to domestic, agricultural and power purposes, while power use was to be subservient to agricultural and domestic uses. The allocation of the water of the two basins was to be made by separate agreements entered into by the states located in each basin.

It was necessary to have the compact ratified by the several states concerned and by the federal government. Arizona would not ratify at all and California ratified only conditionally until the states of the lower basin would enter into an agreement governing the division of waters among the three states of the lower basin.

In the meantime there had been introduced in Congress the so-called Swing-Johnson Bill or Boulder-Canyon Project Act. ${ }^{9}$ This Act was passed in December, I928. It included three principal features. (I) A large dam and reservoir at Boulder or Black Canyon with a storage capacity of $26,000,000$ acre feet; (2) a canal fifty-five miles long to be located entirely within the United States and designed to carry a water supply from the Colorado River to the Imperial and Coachella Valleys in California; (3) a power plant at the dam for the development of electric energy from the waters stored in the reservoir.

By this, it was hoped to solve the flood problem of the lower river, which was a constant danger to the Imperial Valley; to conserve and regulate the flood waters of the river, prevent destruction and make those waters available for the irrigation of lands and to carry a supply of water to Los Angeles and to other cities of southern California for domestic uses. Also, it was assumed that the electric energy which the impounding of the water would make possible would afford a basis for recovery of the cost of the dam and power plant. The passage of this bill was fought by Arizona, but after its passage, negotiations were resumed for the settlement of the problem of the lawer basin. Under the terms of the bill, ${ }^{10}$ if the seven states did not ratify within a certain period, the compact was to go into effect on a six state basis. Arizona did not ratify the compact, and in accordance with the terms of the bill, the project is now being built upon a six state compact. As a result Arizona instituted a proceeding against all the other states and against the Secretary of the Interior. She attacked the compact itself because of its inequitable division of water and asserted further that because she has not ratified the compact it is void and of no effect; that upon the ground that this act is in excess of the powers granted to Congress 
by the Constitution of the United States it is unconstitutional and void, because it attempts to deprive the State of Arizona of its sovereign jurisdiction and control of the water within its state, to subject the state to the Colorado River Compact without its consent and to deprive the state of its right to levy and collect taxes and the business of storing and selling water taken from the tributaries of its state. ${ }^{11}$

Secretary Wilbur and the defendant states filed a motion to dismiss Arizona's bill of complaint, and the case was argued before the Supreme Court March gth and Ioth. On May I8, I93I, the Supreme Court handed down its decision in which it upheld the motion to dismiss the bill of complaint on the grounds (inter alia) that as the river is navigable and the means which the act provides are not unrelated to the control of navigation, the intended project is clearly within the powers conferred by Congress and at present there is no threatened physical interference with any irrigation project approved under the Arizona Law. The court went on to state that if the operations of the dam when it was completed should interfere with any perfected right of Arizona, appropriate remedies would still be available to that state. ${ }^{12}$

This controversy brings into very sharp outline the struggle going on in the western states by reason of their water problems. While it clearly defines the point of disagreement between Arizona and her sister states, there is nothing in the case that constitutes an argument against the use of the compact. In point of fact, it shows the only basis upon which six of those seven states could agree; and still maintain the fullest measure of their sovereignty. It is an outstanding demonstration of the method in which a great empire is being built up, by the recognition in these political bodies of their common economic interest. The manner of dealing with this water problem of the southwest forms a striking example, which might well be followed by the eastern states in meeting questions peculiar to this region. Particularly do these questions arise by reason of the tremendous growth of electrical energy and its wholesale transmission across state lines.

Electrical energy is a vital force of modern civilization. The potentialities involved in its development may be illustrated by reference to certain testimony before the New York Commission on Revision of the Public Service Commissions Law. This testimony showed the possible future construction of vast systems of generating plants, transmission lines and distributing systems, which would completely absorb plants formerly operating

"Arizona claimed that in passing the act, Congress exceeded the powers given to it under Article I, \$ 9, of the Constitution. See brief of complainant (Arizona) in opposition to motions to dismiss the bill of complaint. See also Arizona v. California, infra note I2, at 446 et seq.

${ }^{22}$ Arizona v. California, 283 U. S. 423, 51 Sup. Ct. 522 (193I). 
over a comparatively small area. This would result in the transmission across state lines of huge quantities of electrical power.

A force so necessary to the service of the people must be restricted in the public interest. In that restriction we must have regard not only to the interest of the general public but of the companies themselves and to the investors in those companies.

The difficulties involved in regulation by the state are accentuated by the fact that the companies transmitting such power wholesale across state lines, are usually holding companies, beyond any control of the state, if not the federal government.

In the field of wholesale interstate transmission of power, the Supreme Court has said that in the absence of legislation by Congress, the several states have no authority to regulate ${ }^{13}$ because such regulation would be a direct burden upon interstate commerce.

However, in the case of the sale of natural gas at retail in New York, even where such gas is produced in another state and transported into New York for sale directly to local consumers, the power of New York to regulate the rates for such gas, in the absence of Congressional action, has been upheld on the ground that such commerce is not national in character and does not require general or uniform legislation by Congress. ${ }^{14}$ It has been suggested that a compact between states which would deal with wholesale interstate transmission of power, even though approved by Congress, would be unconstitutional as in violation of the commerce clause.

This phase of the subject has been fully treated in an article by Felix Frankfurter and James Landis. ${ }^{15}$ The authorities collected in that article substantiate the view that agreements between the states for the control of this problem, sanctioned by Congress, would not be in violation of the commerce clause. A compact dealing with a question common to the states concerned and facilitating the regulation within each state of a problem peculiar to itself instead of casting a burden upon interstate commerce constitutes aid to the federal government in dealing with that commerce. And when Congress gives sanction to the compact, it is equivalent to legislation by Congress.

Certainly if the view is accepted that under the decision in the Clark Distilling Case, ${ }^{16}$ Congress has power under the commerce clause by affirmative legislation to permit the states to severally regulate wholesale interstate

${ }^{23}$ Public Util. Com. of R. I. v. Attleboro Steam \& Elec. Co., 273 U. S. 83, 47 Sup. Ct. 294 (1927). (Ig20).

${ }^{1}$ Pennsylvania Gas Co. v. Public Service Com. of N. Y., 252 U. S. 23, 40 Sup. Ct. 279

${ }^{1 s}$ Frankfurter and Landis, The Compact Clause of the Constitution-A Study in Interstate Adjustments (rg25) 34 Y ALE L. J. 685.

${ }^{10}$ Clark Distilling Co. v. Western Md. Ry. Co. and State of W. Va., Clark Distilling Co. v. American Express Co. and State of W. Va., 242 U. S. 3 II, 37 Sup. Ct. I80 (IgI7). 
transmission of power, then it would follow that the states would be free to enter into compacts dealing with this subject. This view is discussed by Professor Noel T. Dowling and William C. Scott. ${ }^{17}$ If this view be accepted, then it is clear that authorization of such compacts by Congress would, by providing such affirmative legislation, remove any barriers to state action contained in the commerce clause.

It has been urged on the other hand that a Federal Commission be set up which would fix rates for power transmitted across a state line and to supervise the method of finance and control of holding companies engaged in interstate transactions. By this method a holding company which sells power to a distributing company across a state line will have the rates fixed by a federal agency.

This proposal involves further concentrated governmental control. It would tend further to undermine the authority and economy of local government. It would mean the intervention in local affairs by an authority far removed from the immediate problems and unfamiliar with the local conditions. Yet some such federal commission is inevitable unless the States of the various sections with a common problem join in an effort to meet that problem themselves rather than submit to an outside agency.

Recognizing the need for joint action, representatives of New York, New Jersey and Pennsylvania met in 1925 for the purpose of studying the regulation of interstate electricity. This group failed to reach a solution because New York disagreed and submitted a memorandum in explanation of its refusal which failed to recognize the purpose and uses and flexibility of a compact. As counsel for the Commission on Revision of the Public Serrice Commissions Law, the writer was called upon to examine witnesses in regard to the desirability and feasibility of such a compact. These witnesses, representing what may be termed both the utilities and public point of view generally admitted the desirability and feasibility of some such plan. In the writer's report to that commission, it was suggested that a body, designated by the State of New York and independent of the Public Service Commission, be appointed to make a general survey of the needs of the state and of the unification of services with other states. The desirability of such a survey has been recognized by the New York legislature and a bill was passed at the I93 $\mathrm{I}$ session providing for the creation of such a commission. ${ }^{18}$ The results of this survey may well show that it

${ }^{17}$ Dowling, State Control of Interstate Power Transmission-The Doctrine of Congressional Permission (May, I930) v. XIV, no. I Proc. ACAD. Pol. Scr. I32; Scott, State and Federal Control of Power Transmission as Affected by the Interstate Commerce Clause, ibid. r35.

${ }^{28}$ N. Y. Laws I931, c. 673 .

This temporary commission was formed to act in conjunction with similar commissions of the states adjoining New York for the purpose of making a survey of utility companies engaged in interstate transmission of power, and by treaties between the several states and the federal government to effectually regulate and control interstate transmission. 
is only by means of negotiation and agreement with other states that New York can hope to solve her power problems.

Because of its flexibility in adapting methods of control to the particular problems of the localities concerned, the use of the compact could be greatly extended.

In an address before the Oil Relief Conference, ${ }^{19}$ January I6th, called by the governors of the oil-producing states, Ray Lyman Wilbur, Secretary of the Interior, reviewed the conditions prevailing in the oil industry as a result of overproduction and stated that he saw "no substantial lasting remedy except that of a compact between the oil-producing states, approved by Congress, so that there will be fair play, reasonable and sensible planning, unit operation where possible, and a proper protection of seasoned and established oil-producing areas when they come in contact with flush field." Regulation of the liquor traffic which is peculiarly dependent upon the varying customs and attitude of mind of the inhabitants of different localities, particularly lends itself to this method of control.

The importance of the use of the compact is, however, not confined to its adaptability to problems essentially local or regional. It can be made an effective instrument for the preservation and restoration to the states of local control and administration of local problems. A survey of the present and probable future demands upon federal regulatory and enforcement agencies forcibly indicates that it will be physically impossible for the machinery of the federal government to carry the tremendous burden. The enforcement of prohibition, the regulation of rates, practices and service of railroads and the consideration of plans for their consolidation, the development of water power resources and the myriad obligations now imposed upon the central government furnish ample evidence that it cannot be called upon to assume all of the burden and all of the responsibility. But, even should the federal government be provided with the funds necessary to effect the huge and intricate organization that would be required, it could not be supposed that federal action would result in as harmonious or as effective a working out of these problems as the combined efforts of the states concerned. The political philosophy underlying these problems was aptly expressed early in the nineteenth century by Alexis de Tocqueville: ${ }^{20}$

"The partisans of centralization in Europe are wont to maintain that the government can administer the affairs of each locality better than the citizens could do it for themselves: this may be true, when the central power is enlightened, and the local authorities are ignorant; when it is alert, and they are slow; when it is accustomed to act, and they to obey. Indeed, it is evident that this double tendency must augment with the increase of centralization, and that the readiness of 
the one and the incapacity of the others must become more and more prominent. But I deny that it is so, when the people are as enlightened, as awake to their interests, and as accustomed to reflect on them, as the Americans are. I know it is difficult to point out with certainty the means of arousing a sleeping population. . . . But whenever a central administration affects completely to supersede the persons most interested, I believe that it is either misled, or desirous to mislead. However enlightened and skillful a central power may be, it cannot of itself embrace all the details of the life of a great nation.

". . . Its force deserts it, when society is to be profoundly moved, or accelerated in its course; and if once the co-operation of private citizens is necessary to the furtherance of its measures, the secret of its impotence is disclosed. Even whilst the centralized power, in its despair, invokes the assistance of the citizens, it says to them: 'You shall act just as I please, as much as I please, and in the direction which I please. You are to take charge of the details, without aspiring to guide the system; you are to work in darkness; and afterwards you may judge my work by its results.' These are not the conditions on which the alliance of the human will is to be obtained. . . ."

Today the United States is a union of individual regions. State lines are boundaries of political demarcation and do not coincide with larger regional boundaries of which the state is a part. Regional areas exist as the result of elementary physical and social conditions. Men living in the same area have identical forces of nature to combat, similar problems of adjustment to solve, and possess as a result common customs, viewpoints and economic aims. Our nation includes a vast domain of varied territory. Though we possess a common language, there exists a wide diversity of regional characteristics. The problems of the deserts in the southwest are peculiarly their own. The densely populated areas of the eastern seaboard do not have the same situations to meet that confront the agricultural areas of the midwest, the grain and timber lands of the northwest or the cotton plantations of the south. Each one is an empire in itself, and each one embraces several states.

States in order to function more completely in their local affairs must be able to work in harmony with those neighboring states possessing the same aims and characteristics.

Regional considerations so vital to the fullest development of a homogeneous territory in this way can be given thorough and comprehensive treatment. The federal government relieved of a measure of its burden can function more completely within those fields in which it is a necessary and vital agency. Rivalries and inadequacies of litigation can be supplanted by conference and compromise based on scientific and practical information, and a finer balance of power can be developed between state and nation. 